\title{
Faktor-Faktor Penyebab Utang Luar Negeri dan Dampaknya Terhadap Pertumbuhan Ekonomi Indonesia
}

\author{
Nunu Nugraha*, Kamio, Diah Setyorini Gunawan \\ Fakultas Ekonomi dan Bisnis, Universitas Jenderal Soedirman \\ *Correspondence email: nugrahanunu0408@gmail.com
}

\begin{abstract}
Abstrak. Tujuan dalam penelitian ini adalah menguji dan menganalisis pengaruh pengeluaran pemerintah, nilai tukar, dan pertumbuhan ekonomi negara peminjam terhadap utang luar negeri Indonesia, serta dampak utang luar negeri pada pertumbuhan ekonomi. Metode regresi linear berganda dan pengujian (uji t dan uji F) digunakan sebagai alat analisis dalam penelitian ini. Kesimpulan penelitian ini adalah pengeluaran pemerintah mempunyai pengaruh signifikan terhadap utang luar negeri sedangkan nilai tukar dan pertumbuhan ekonomi negara peminjam tidak mempunyai pengaruh signifikan terhadap utang luar negeri. Secara bersama-sama pengeluaran pemerintah, nilai tukar dan pertumbuhan ekonomi negara peminjam terdapat pengaruh signifikan terhadap utang luar negeri Indonesia tahun 2001-2017. Sementara itu, utang luar negeri juga ada pengaruh yang signifikan terhadap pertumbuhan ekonomi di Indonesia tahun 2001-2017.
\end{abstract}

Kata Kunci: Pengeluaran Pemerintah; Nilai Tukar; Negara Peminjam; Utang Luar Negeri; Pertumbuhan Ekonomi.

\begin{abstract}
This research aims to examine and analyze the effect of government spending, exchange rate, and Debtor economic growth on Indonesia's foreign debt, as well as the impact of external debt on economic growth. The tools of the analysis in this research used multiple linear regression method and use test (t-test and F-test). The result of study indicated government expenditures have a significant effect on foreign debt while debtor country exchange rate and economic growth have no significant effect on external debt. Simultaneously government spending, debt country, exchange rate and economic growth significantly affected Indonesia's foreign debt in 2001-2017. Meanwhile, foreign debt has significant effect on economic growth in Indonesia in 2001-2017.
\end{abstract}

Keywords: Government expenditure; exchange rate; Debtor growth; foreign debt; economic growth.

\section{PENDAHULUAN}

Keterbatasan biaya pembangunan menjadi masalah utama negara-negara berkembang dalam memajukan segala sektor pembangunan. Sebagai negara berkembang, biaya yang digunakan Indonesia dalam pembangunan tentunya tidak sedikit. Kekurangan biaya di dalam negeri menjadi alasan utama Indonesia melakukan utang luar negeri (ULN). Dalam beberapa catatan, Indonesia mulai melakukan utang luar negeri dimulai pada masa orde lama dengan tujuan menambah sokongan dana untuk melunasi kekurangan dana pembangunan yang tidak bisa dipenuhi dalam negeri.

Sumber pembiayaan suatu negara bisa dilihat dari sisi pendapatan yang diperoleh dari pemasukan pembiayaan negara. Selain itu, pembiayaan berhubungan dengan pengeluaran pemerintah mengenai belanja negara dalam suatu periode. Seperti halnya kebutuhan sehari-hari, dalam belanja negara juga memiliki kebutuhan yang bersifat primer (utama) dan juga yang bersifat sekunder (tambahan) serta kebutuhan yang tidak terduga. Berdasarkan laporan Bank Indonesia, (2018) jumlah utang luar negeri Indonesia pada periode 1 tahun 2018 sebesar USD 357,5 miliar atau sama dengan Rp $4.034,80$ triliun. Angka ini mengalami kenaikan sebesar $13,46 \%$ bila dibandingkan dengan periode yang sama di tahun 2017. Tahun 2013 utang luar negeri Indonesia adalah 3.632 triliun rupiah. Angka ini terus naik di tahun 2014 yang mencapai 4.049 triliun rupiah. Kenaikan
Kembali terjadi pada tahun 2015 yaitu naik 121 triliun menjadi 4.170 triliun rupiah. Kemudian tahun berikutnya terus mengalami kenaikan hingga yang tertinggi yaitu tahun 2017 yaitu mencapai 4.683 triliun rupiah.

Utang luar negeri Indonesia merupakan isu yang sangat menarik untuk diteliti lebih lanjut. Hal tersebut didasarkan bahwa pemerintah dalam memutuskan untuk menambah utang tentu dipengaruhi oleh banyak factor. Selain itu, utang luar negeri tentu memiliki dampak terhadap pembanguan serta perumbuhan ekonomi Indonesia. Dengan demikian penelitan ini bertujuan menganalisis pengaruh nilai tukar, pengeluaran pemerintah, dan pendapatan pemerintah terhadap utang luar negeri dan apakah pertunbuhan ekonomi di Indonesia dipengaruhi oleh hutang luar negeri pada periode 2001-2017.

\section{Utang Luar Negeri}

(Widharma et al, 2012) terdapat sudut pandang yang berbeda dalam melihat dan menelaah pinjaman luar negeri atau utang luar negeri. Penelahaan dari sudut pandang pemberi pinjaman atau kreditur dilihat dari berbagai faktor kemungkinan adanya pengembalian pinjaman pada waktunya dan mendapat manfaat tertentu. Sementara itu, penelaahan dari sisi penerima pinjaman atau debitur dilihat dari faktor adanya kemungkinan dalam memperoleh manfaat dan penggunaan secara maksimal agar dapat menambah pertumbuhan 
perekonomian. Utang luar negeri adalah modal yang diberikan oleh negara lain (luar negeri) yang digunakan untuk meningkatkan modal keperluan dalam negeri merupakan sudut pandang dari faktor materiil. Sedangkan berdasarkan aspek formal, peningkatan investasi karena adanya penerimaan atau pemberian sebagai upaya menunjang pertumbuhan ekonomi dapat diartikan sebagai utang luar negeri. Pinjaman luar negeri adalah sumber pembiayaan alternatif yang digunakan dalam pembangunan merupakan pengertian yang didasarkan pasa aspek fungsi.

Cara yang efektif dalam menutup kekurangan anggaran (defisit anggaran) pemerintah pusat melalui utang luar negeri yang didapatkan dengan menjalin hubungan kerjasama antara negara kreditur dengan negara debitur dimana risiko yang terjadi lebih kecil dibandingkan mencetak uang (seignorage) yang bisa menimbulkan inflasi (Atmadja, 2000). Menurut (Sukirno, 1978) utang luar negeri dapat diartikan sebagai aliran dana yang diperoleh dari luar negeri, apabila tujuan dari aliran dana tersebut bukan untuk mencari keuntungan dan hanya memberlakukan syarat yang ringan dibandingkan pasar internasional.

Untuk negara berkembang, utang luar negeri berdampak pada perekonomian baik positif maupun negatif. Namun, utang luar negeri dapat menjadi masalah bagi negara peminjam apabila utang yang terlalu besar sehingga pembangunan ekonomi yang terjadi terperangkap dalam hutang (debt trap) yang akhirnya negara tidak lepas dari negara kreditur (Ispriyahadi et al, 2019)

\section{Pengeluaran Pemerintah}

Dalam teori Keynes (Sukirno, 2004) bahwa perekonomian yang diatur oleh pasar bebas akan menyebabkan tidak tercapainya tingkat kesempatan kerja penuh dan kestabilan ekonomi menjadi tidak maksimal karenanya diperlukan adanya peranan atau campur tangan pemerintah dalam perekonomian. Akan tetapi kesempatan kerja dan pengangguran akan memiliki dampak serius apabila kegiatan ekonomi yang berfluktuasi besar dari waktu ke waktu.

Kebijakan pemerintah dapat dicerminkan melalui besarnya pengeluaran pemerintah (Dumairi, 1999). Kebijakan pemerintah terkait pembelian barang dan jasa akan tercerminkan dalam pengeluaran pemerintah dalam membiayai barang dan jasa tersebut. Penggolongan pengeluaran pemerintah dapat dibagi menjadi dua, yaitu teori mikro dan teori makro. Teori dari sisi makro akan dikedepankan dalam penelitian ini. Terdapat tiga golongan perkembangan pengeluaran pemerintah berdasarkan teori makro yang dikemukakan oleh para ahli ekonomi, yaitu perkembangan aktivitas pemerintah dalam hukum wagner, teori Peacock, model pembangunan pengeluaran pemerintah, dan Wiseman.

Rostow dan Musgrave mengembangkan model pembangunan mengenai perkembangan pengeluaran pemerintah dalam ekonomi, dimana tahapan pembangunan ekonomi yang terdiri dari awal, menengah, dan lanjut akan dihubungkan dengan pengeluaran pemerintah tersebut. Pada tahap awal pemerintah menyediakan prasarana dan insfratruktur seperti pendidikan, transportasi, kesehatan dalam upaya peningkatan perekonomian sehingga jumlah investasi pemerintah menjadi besar.

\section{Nilai Tukar}

(Simi, 2015) Dua mata uang berbeda yang dipertukarkan dengan membandingkan nilai atau harga antara keduanya dinamakan kurs (exchange rate). Nilai Tukar Rupiah merupakan nilai mata uang rupiah yang dibandingkan dengan negara lain. (Boediono, 1981) menyatakan bahwa keseimbangan mata uang dalam negeri ataupun luar negeri yang dilihat pada sisi permintaan dan penawaran dapat dicerminkan oleh nilai tukar. Penurunan permintaan masyarakat terhadap mata uang rupiah direfleksikan oleh niai tukar rupiah yang menurun dimana disebabkan karena terjadinya penurunan peran ekonomi nasional atau adanya permintaan mata uang asing sebagai alat pembayaran internasional yang meningkat. Kinerja di pasar uang yang mengalami peningkatan dan perbaikan ditandai adanya penguatan kurs nilai rupiah. Pelemahan nilai tukar domestik pada mata uang asing disebabkan adanya dampak dari peningkatan laju inflasi.

\section{Laju Pertumbuhan Ekonomi}

Pertumbuhan ekonomi ditandai dengan kegiatan dalam perekonomian berkembang dan mengakibatkan peningkatan produksi barang dan jasa serta adanya peningkatan kemakmuran masyarakat (Kumorotomo, 2004). Masalah makroekonomi dalam jangka panjang melihat permasalahan dalam pertumbuhan ekonomi. Kemampuan suatu negara dalam peningkatan barang dan jasa yang diproduksi harus selalu terjadi dalam satu waktu ke waktu lainnya. Peningkatan kemampuan ini terjadi karena adanya tambahan faktor-faktor produksi baik dalam jumlah kuantitas maupun kualitasnya. Aktivitas perekomian dalam mengahasilkan tambahan pendapatan masyarakat ditunjukan oleh sejauh mana pertumbuhan ekonomi teradi pada suatu periode tertentu. Pada dasarnya aktivitas perekonomian merupakan suatu proses produksi yang memyebabkan balas jasa dari adanya penggunaan faktor produksi dalam memproduksi output tersebut. Adanya pertumbuhan ekonomi diharapkan juga dapat meningkatkan pendapatan masyarakat sebagai pemilik faktor produksi (Sukirno, 2004).

Pertumbuhan ekonomi terjadi apabila dalam jangka panjang terjadi proses peningkatan output perkapita (Boediono, 1981). Sedangkan menurut Simon Kuznetz (Sukirno, 2004) kapasitas ditingkatkan dalam jangka panjang dari suatu negara dalam upaya agar berbagai barang ekonomi dapat tersedia kepada 
penduduknya dinamakan sebagai pertumbuhan ekonomi. Definisi pertumbuhan ekonomi yang lain adalah bahwa adanya kenaikan output perkapita menyebabkan pertumbuhan ekonomi sehingga pertumbuhan ekonomi menggambarkan adanya peningkatan taraf hidup yang diukur dengan output riil per orang dalam konteks yang kedua tersebut. hasil pembangunan nasional yang dilihat melalui kemajuan ekonomi diukur oleh laju pertumbuhan ekonomi, sedangkan tingkat kemakmuran penduduk diukur melalui pendapatan perkapita sebab pendapatan perkapita yang meningkat menyebabkan semakin tingginya tingkat kemakmuran penduduk dan juga produktivitasnya (Basri, 1999).

\section{METODE}

Objek penelitian ini adalah utang luar negeri sebagai variable terikat, dan tiga variable bebas yaitu pengeluaran pemerintah, nilai tukar, pertumbuhan ekonomi Singapura tahun 2001-2017. Kemudian laju pertumbuhan ekonomi senagai variable terikat, dan satu variable bebas yaitu utang luar negeri tahun 2001-2017. Berikut ini adalah definisi dari variabel penelitian yang ditunjukkan pada Tabel 1.

Tabel 1. Definisi Operasional Variabel Penelitian

\begin{tabular}{|c|c|c|c|}
\hline Variabel & Penjelasan & Satuan & Skala \\
\hline Utang Luar Negeri & $\begin{array}{l}\text { Utang Luar Negeri Indonesia pada setiap tahun termasuk didalamnya utang } \\
\text { pemerintah dan utang swasta diperoleh dari laporan berkala Bank Indonesia. }\end{array}$ & Rupiah & Rasio \\
\hline Pertumbuhan Ekonomi & $\begin{array}{l}\text { Kenaikan perekonomian dibandingkan dengan tahun sebelumnya sehingga } \\
\text { menghasilkan angka persentase pada pengamatan tahun 2001-2017. }\end{array}$ & Persen & Rasio \\
\hline $\begin{array}{l}\text { Pengeluaran } \\
\text { Pemerintah }\end{array}$ & $\begin{array}{l}\text { Kegiatan realisasi anggaran pemerintah pertahun pada periode anggaran 2001- } \\
20017 \text {. }\end{array}$ & & Rasio \\
\hline Nilai Tukar & $\begin{array}{l}\text { Nilai mata uang rupiah dibandingkan dengan mata uang Internasional (USD), kurs } \\
\text { yang diambil adalah kurs tengah pada pengamatan tahun 2001-2017 }\end{array}$ & Rupiah & Rasio \\
\hline $\begin{array}{l}\text { Pertumbuhan Ekonomi } \\
\text { Negara Peminjam }\end{array}$ & $\begin{array}{l}\text { Perkembangan perkonomian Singapura yaitu perubahan dibandingkan dengan tahun } \\
\text { sebelumnya sehingga menghasilkan angka persentase pada pengamatan tahun } 2001 \text { - } \\
2017 \text {. }\end{array}$ & Persen & Rasio \\
\hline
\end{tabular}

Untuk menganalisis tujuan penelitian menggunakan metode regresi linier berganda dan reggresi sederhana dengan model OLS (Ordinary Least Square) (Gujarati dan Porter, 2010). Dalam penelitian ini, persamaan dasar yang dipakai adalah sebagai berikut

$\mathrm{Y}_{1}=\mathrm{f}\left(\mathrm{X}_{1}, \mathrm{X}_{2}, \mathrm{X}_{3}\right) \ldots \ldots$ (1)

$\mathrm{Y}_{2}=\mathrm{f}\left(\mathrm{Y}_{1}\right) \ldots \ldots \ldots \ldots .(2)$

Dari persamaan 1 dikembangkan menjadi persamaan ekonometrika dalam penelitian ini. Berikut persamaan regresi linier berganda yang berfungsi untuk menjawab tujuan penelitian pertama.

$\log Y_{1}=\alpha+\beta_{1} \log X_{1}+\beta_{2} \log X_{2}+\beta_{3} X_{3}+$ et... (3)

Keterangan:

$\mathrm{Y}_{1} \quad=$ Utang Luar Negeri

$\alpha \quad=$ Konstanta

$\beta_{1,2,3}=$ Koefisien Regresi

$\mathrm{X}_{1} \quad=$ Pengeluaran Pemerintah

$\mathrm{X}_{2} \quad=$ Nilai Tukar

$\mathrm{X}_{3} \quad=$ Pendapatan Pemerintah

Et $=$ Tingkat kesalahan pengganggu / error

Selanjutnya mengacu pada persamaan 2 yang digunakan untuk menjawab tujuan penelitian kedua yaitu pertumbuhan ekonomi yang dipengaruhi oleh utang luar negeri. Berikut persamaan penelitian kedua yang digunakan dalam penelitian ini.
$\mathrm{Y}_{2}=\beta_{0}+\beta_{1} \log \mathrm{Y}_{1}+$ et

Keterangan:

$\mathrm{Y}_{2} \quad=$ Pertumbuhan Ekonomi

$\beta_{0} \quad=$ Konstanta

$\beta_{1} \quad=$ Koefisien $\mathrm{Y} 1$

$\mathrm{Y}_{1} \quad=$ Utang Luar Negeri

Et = Tingkat kesalahan pengganggu / error

Dalam mengetahui apakah model regresi tersebut merupakan model regresi yang baik atau tidak dapat dilakukan dengan menggunakan uji asumsi klasik. uji normalitas, multikolineritas, heteroskedastisitas, dan autokorelasi digunakan dalam penelitian ini guna uji asumsi klasik (Gujarati dan Porter, 2010).

\section{HASIL DAN PEMBAHASAN}

Dalam menganalisis pengaruh pengaruh pengeluaran pemerintah, nilai tukar, dan pendapatan pemerintah terhadap utang luar negeri pada periode 2001-2017 di Indonesia, regresi linier berganda digunakkan dalam penelitian ini. Namun sebelum menginterprestasikan hasil regresi, output regresi terlebih dahulu harus lolos uji asumsi klasik. Namun demikian dalam penelitian ini hasil regresi menyatakan lolos uji asumsi klasik, sehingga hasil regresi dapat diinterprestasikan lebih lanjut. Berikut ini ringkasan output regresi yag menganalisis pengaruh pengeluaran pemerintah, nilai tukar, dan pendapatan pemerintah terhadap utang luar negeri di Indoensia pada periode tahun 2001-2017. 
Nunu Nugraha, Kamio dan Diah Setyorini Gunawan, Faktor-Faktor Penyebab Utang Luar Negeri dan Dampaknya Terhadap Pertumbuhan Ekonomi Indonesia

Tabel 2. Ringkasan Output regresi persamaan 3

\begin{tabular}{|c|c|c|c|}
\hline Variabel & Koefisien & T-Statistik & Prob. \\
\hline LOG(PP) & 0,5379 & 9,5762 & 0.0000 \\
\hline LOG(NT) & 0,3581 & 1,5394 & 0.1477 \\
\hline PS & $-0,0025$ & $-0,3847$ & 0.7067 \\
\hline Adjusted $R$-squared & 0,9433 & & \\
\hline F-statistic & 89,8553 & \multicolumn{3}{|l}{} \\
\hline
\end{tabular}

Sumber: Output regresi

Selain menganalisis pengaruh pengeluaran pemerintah, nilai tukar, dan pendapatan pemerintah terhadap utang luar negeri di Indonesia pada tahun 20012017. Penelitian ini juga menganalisis pengaruh antara utang luar negeri dengan pertumbuahan ekonomi di Indonesia pada periode tahun 2001-2017. Berikut ini ringkasan output regresi pengaruh utang luar negeri terhadap pertumbuhan ekonomi.

Tabel 3. Ringkasan Output regresi persamaan 4

\begin{tabular}{|c|c|c|c|}
\hline Variabel & Koefisien & T-Statistik & Prob. \\
\hline LOG(ULN) & 0,6354 & 2,4408 & 0,0275 \\
\hline Adjusted $R$-squared & 0.236561 & \multicolumn{3}{|l}{} \\
\hline
\end{tabular}

Sumber: Output regresi

\section{Pengaruh Pengeluaran Pemerintah terhadap utang Luar Negeri tahun 2001-2017}

Dilihat dari hasil regresi menggunakan derajat keyakinan 95 persen bahwa variabel pengeluaran pemerintah mempunyai pengaruh signifikan dengan hubungan yang positif dengan utang luar negeri. Hal ini didukung oleh hasil koefisien regresi sebesar 0,538 yang berarti ketika pengeluaran pemerintah naik sebesar 1 persen saat nilai tukar dan pertumbuhan ekonomi Singapura tetap, maka utang luar negeri naik sebesar 0,538 persen. Hasil penelitian di atas didukung dengan penelitian (Widharma et al. 2012) yang menyatakan bahwa secara parsial adanya pengaruh signifikan dari pengeluaran pemerintah dengan hubungan yang positif terhadap utang luar negeri Indonesia. Penelitian ini pula memperoleh hasil yang sama dengan Harahap (2007) yang mengemukakan bahwa pengeluaran pemerintah sangat memberi kontribusi terhadap besarnya utang luar negeri serta berpengaruh signifikan dan berhubungan positif.

Beberapa faktor menyebabkan signifikannya pengeluaran pemerintah terhadap utang luar negeri diantaranya kebiasaan pemerintah yang menginginkan dana cepat untuk pembangunan dan menutup pengeluaran yang lebih besar daripada pendapatan. Tingginya biaya subsidi bahan bakar minyak dan kesehatan menyebabkan pembiayaan pemerintah semakin besar sehingga utang luar negeri menjadi altrnatif dalam menutup pembiayaan. (Saleh, 2008) menyatakan bahwa pemerintah belum bisa melakukan efektivitas pembiayaan subsidi, menekan biaya restrukturisasi perbankan, mengendalikan peningkatan pengeluaran belanja pegawai.

\section{Pengaruh Nilai Tukar terhadap Utang Luar Negeri tahun 2001-2017}

Dilihat dari hasil regresi menggunakan derajat keyakinan 95 persen bahwa variabel nilai tukar tidak mempunyai pengaruh yang signifikan dengan hubungan yang positif dengan utang luar negeri seperti pada hasil koefisien regresi sebesar 0,358 yang berarti ketika nilai tukar naik sebesar 1 persen saat pengeluaran pemerintah dan pertumbuhan ekonomi Singapura tetap, maka utang luar negeri naik sebesar 0,358 persen. Hasil penelitian ini memiliki kesamaan dengan penelitian (Saleh, 2008), yang menyimpulkan bahwa nilai tukar dan utang luar negeri tidak mempunyai pengaruh yang signifikan. Namun berbeda dengan sebelumnya oleh (Widharma et al. 2012) yang menyimpulkan bahwa kurs dolar memiliki pengaruh signifikan terhadap utang luar negeri pemerintah. (Sukirno, 1978), yang menyimpulkan bahwa resiko dialami Indonesia salah satunya adalah adanya utang luar negeri dalam bentuk valuta asing, sehingga dapat menyebabkan cukup besarnya kurs utang luar negeri. Oleh karena itu, adanya apresiasi atau depresiasi rupiah terhadap mata uang asing memiliki dampak bagi utang luar negeri. Utang luar negeri Indonesia yang pembayarannya melalui valuta asing akan bertambah apabila terjadi depresiasi rupiah demikian pula sebaliknya. Resiko dari kurs ini bukan hanya dapat mengakibatkan beratnya pengeluaran dalam APBN tetapi juga perekonomian nasional.

Utang luar negeri yang meningkat disebabkan oleh dua per tiganya karena defisit neraca pembayaran sedangkan sepertiga disebabkan fluktuasi nilai tukar. Hasil penelitian ini memperkuat Kementrian Keuangan (2011), yang dalam Laporan Keuangan Pemerintah Pusat (LKPP) mengemukakan bahwa utang luar negeri indonesia dalam rupiah semakin membesar setiap tahunnya apabila terjadi depresiasi rupiah karena berdasarkan kesepakatan dari negara peminjam, maka utang luar negeri yang diambil berbentuk valuta asing khusunya US Dollar. Selain itu salah satu alasan penyebab tidak terjadinya signifikansi variabel nilai tukar yaitu ketika nilai tukar terdepresiasi maka akan mendorong kegiatan ekspor suatu negara dan dari hasil ekspor tersebut bertujuan untuk membayar utang luar negeri sehingga akan mengurangi utang luar negeri yang dimiliki Indonesia.

\section{Pengaruh Pertumbuhan Ekonomi Singapura terhadap Utang Luar Negeri tahun 2001-2017 \\ Didasarkan pada hasil regresi yang menggunakan} derajat keyakinan 95 persen bahwa variabel pertumbuhan ekonomi Singapura tidak berpengaruh signifikan dan memiliki hubungan yang negatif dengan utang luar negeri. Hal ini didasarkan pada koefisien regresi sebesar -0,0025 yang berarti ketika pertumbuhan ekonomi Singapura naik sebesar 1 persen saat pengeluaran pemerintah dan nilai tukar tetap, maka utang luar negeri turun sebesar 0,0025 persen. Hasil 
penelitian didukung oleh penelitian (Cholifihani, 2008) yang menyatakan bahwa economic growth tidak memiliki pengaruh signifikan terhadap utang luar negeri namun bedanya adalah menurut penelitian Zahoor yang menyatakan bahwa economic growth berhubungan positif. Penelitian ini juga tidak sejalan seperti Karagol (2002) menyimpulkan bahwa aliran dana masuk termasuk didalamnya utang luar negeri sangat dipengaruhi oleh laju pertumbuhan ekonomi.

Penyebab tidak signifikannya pertunbuhan ekonomi Singapura terhadap utang luar negeri Indonesia diantaranya dikarenakan Singapura merupakan negara yang sudah maju dan tidak mudah untuk mendapatkan pertumbuhan ekonomi yang besar karena sumber dayanya yang sudah mendekati full employment (Rudi and Rotinsulu, 2016). Selain itu, hal ini menandakan bahwa Indonesia memiliki ketergantungan dengan utang luar negeri (Sastrawan, 2014).

\section{Pengaruh Utang Luar Negeri terhadap Pertumbuhan Ekonomi Indonesia Tahun 2001 - 2017}

Dilihat dari hasil regresi dengan derajat keyakinan 95 persen bahwa variabel utang luar negeri tidak mempunyai pengaruh yang signifikan dan terdapat hubungan yang positif dengan utang luar negeri. Hal ini didukung dari hasil koefisien sebesar 0,635 yang mengartikan bahwa ketika utang luar negeri naik sebesar 1 persen maka akan meningkatkan laju pertumbuhan sebesar 0,635 persen. Hasil penelitian ini didukung oleh penelitian (Cholifihani, 2008) mengemukakan bahwa pengaruh yang signifikan dengan hubungan positif antara utang luar negeri dengan pertumbuhan ekonomi Indonesia. Namun, dalam penelitian ini tidak sejalan dengan (Rudi and Rotinsulu, 2016) yang mengemukakan bahwa terdapat pengaruh dengan hubungan yang positif dan tidak signifikan antara utang luar negeri dengan pertumbuhan ekonomi. Utang luar negeri yang signifikan dapat bias terjadi apabila ada efektivitas dana utang luar negeri untuk pembangunan (Saleh, 2008).

\section{SIMPULAN}

Hasil penelitian menyimpulkan bahwa ada pengaruh signifikan antara pengeluaran pemerintah dan utang luar negeri dengan hubungan yang positif. Nilai tukar tidak mempunyai pengaruh yang signifikan dan memiliki hubungan positif, sedangkan pertumbuhan ekonomi Singapura mempunyai hubungan yang negatif dan tidak nemiliki pengaruh signifikan terhadap utang luar negeri Indonesia pada pengamatan tahun 2001 2017. Sementara itu, pertumbuhan ekonomi Indonesia dapat terdampak cukup kuat dengan adanya utang luar negeri karena utang luar negeri memiliki pengaruh signifikan dengan hubungan positif terhadap pertumbuhan ekonomi Indonesia dengan pengamatan tahun 2001 - 2017.

Penelitian ini merekomendasikan setiap kebijakan pemerintah harus memperhatikan dan menstabilkan nilai tukar serta mampu mencari bentuk kebijakan ekonomi yang dapat memenuhi pengeluaran pemerintah. Selain itu, untuk penelitian selanjutnya yang akan membahas penelitian tebtang utang luar negeri dan pertumbuhan ekonomi, dapat menambah variabel dan jangka waktu penelitian.

\section{DAFTAR PUSTAKA}

Atmadja, A. S. (2000). Utang Luar Negeri Pemerintah Indonesia: Perkembangan Dan Dampaknya. Akuntansi Dan Keuangan 2(1):83-94.

Anon. n.d. PP 10 Tahun 2011.

Basri, F. (1999). Perekonomian Indonesia Menjelang Abad XXI. Jakarta: Erlangga.

Bank Indonesia. (2018). Laporan Berkala BI Mengenai Pinjaman Luar Negeri Indonesia Tahun 20012017. Jakarta.

Boediono. B. (1981). Ekonomi Internasional. Yogyakarta: Gadjah Mada University Press.

Cholifihani, M. (2008). A Cointegration Analysis of Public Debt Service and GDP in Indonesia.Journal of Management and Social Sciences 4(2):68-81.

Dumairi, D. (1999). Perekonomian Indonesia. Jakarta: Erlangga.

Gujarati, D.N. dan D.C. Porter. (2010). Dasar-Dasar Ekonometrika, Edisi 5. Jakarta: Salemba Empat

Harahap, M, D, M. (2007). Analisis Faktor-faktor yang mempengaruhi Utang luar negeri Indonesia. Tesis Magister Ekonomi Pembangunan. Program Pasca Sarjana Universitas Sumatera Utara.

Ispriyahadi, H., Nuryartono, N., Manurung, A. H., \& Hakim, D. B. (2019). Pengaruh Utang Luar Negeri Swasta Terhadap Pertumbuhan Ekonomi Di Indonesia.1-15.

Karagol, E. (2002). The Causality Analysis of External Debt Service and GNP: The Case of Turkey, Central Bank Review, 39-64.

Kumorotomo, W. (2004). Desentralisasi Fiskal Politik Dan Perubahan Kebijakan 1974-2004. Yogyakarta: Global Book.

Rudi, M, I., Rotinsulu, T. O., \& Tenda, A. (2016). Pengaruh Utang Luar Negeri Dan Penanaman Modal Asing Terhadap Pertumbuhan Ekonomi Indonesia Periode Tahun 2009.3-2014.4. Jurnal Berkala Ilmiah Efisiensi 16(2):325-33.

Saleh, S. (2008). Faktor-Faktor Yang Mempengaruhi Pinjaman Luar Negeri Serta Imbasnya Terhadap APBN. Unisia 31(70):343-63.

Sastrawan, H. (2014). Keadaan Ekonomi Singapura.

Simi, A. B. (2015). Pengaruh Utang Luar Negeri Dan Fluktuasi Nilai Tukar Rupiah Terhadap Pertumbuhan Ekonomi Indonesia ( Studi Pada Bank Indonesia Tahun 2003-2013). Jurnal Administrasi Bisnis 28(2): 1-9. 
Nunu Nugraha, Kamio dan Diah Setyorini Gunawan, Faktor-Faktor Penyebab Utang Luar Negeri dan Dampaknya Terhadap Pertumbuhan Ekonomi Indonesia

Sukirno, S. (1978). Ekonomi Pembangunan: Proses, Masalah, Dan Dasar Kebijakan. Depok: Lembaga Penerbit Fakultas Ekonomi Universitas Indonesia.

Sukirno, S. (2004). Makroekonomi: Teori Pengantar. Jakarta: Raja Grafindo Persada.

Widharma, I. W. G., Budhi, I. M. K. S., \& Marhaeni, A. A. I. N. (2012). Utang Luar Negeri Pemerintah Indonesia: Kajian Terhadap Faktor-Faktor Yang Berpengaruh. E-Journal Pascasarjana Univ Udayana 2(1):1-20. 